\title{
CAN A PRESEPSIN (SCD14-ST) OBTAINED FROM TRACHEAL ASPIRATE BE A BIOMARIER FOR EARLY- ONSET NEONATAL SEPSIS
}

\author{
Dragana Savic $^{1,2}$, Aleksandra Simovic ${ }^{1,2}$, Radiša Pavlovic ${ }^{3}$, Sanja Knezevic ${ }^{1,2}$, Nevena Folic ${ }^{1,2}$, \\ Bojana Trikos ${ }^{4}$, Zorana Djordjevic ${ }^{5}$ and Zoran Igrutinovic ${ }^{1,2}$ \\ ${ }^{1}$ University of Kragujevac, Serbia, Faculty of Medical Sciences, Department of Pediatrics \\ ${ }^{2}$ Clinical Center Kragujevac, Pediatric Clinic, Kragujevac, Serbia \\ ${ }^{3}$ University of Kragujevac, Serbia, Faculty of Medical Sciences, Department of Clinical Pharmacy \\ ${ }^{4}$ Medical center "Studenica" Kraljevo, Serbia \\ ${ }^{5}$ Clinical Center Kragujevac, Department for the control and prevention of hospital infections, Kragujevac, Serbia
}

\author{
MOŽE LI PRESEPSIN (SCD14-ST) DOBIJEN IZ TRAHEALNOG \\ ASPIRATA BITI BIOMARIER ZA RANO OTKRIVANJE SEPSE \\ KOD NOVOROĐENE DECE \\ Dragana Savić ${ }^{1,2}$, Aleksandra Simović ${ }^{1,2}$, Radiša Pavlović ${ }^{3}$, Sanja Knežević ${ }^{1,2}$, Nevena Folić ${ }^{1,2}$, \\ Bojana Trikoš ${ }^{4}$, Zorana Đorđević ${ }^{5}$ i Zoran Igrutinović ${ }^{1,2}$ \\ ${ }^{1}$ Univerzitet u Kragujevcu, Fakultet medicinskih nauka, Katedra za pedijatriju, Srbija \\ ${ }^{2}$ Klinički Centar Kragujevac, Klinika za pedijatriju, Kragujevac, Srbija \\ ${ }^{3}$ Univerzitet u Kragujevcu, Fakultet medicinskih nauka, Katedra za klinčku farmakologiju, Srbija \\ ${ }^{4}$ Medicinski centar "Studenica" Kraljevo, Srbija \\ ${ }^{5}$ Klinički Centar Kragujevac, Odeljenje za kontrolu i prevenciju intrahospitalnih infekcija, Kragujevac, Srbija
}

Received / Primljen: 16. 05. 2018.

Accepted / Prihvaćen: 11. 07. 2018.

\begin{abstract}
In absence of clear clinical signs and clear definition, neonatal sepsis is still one of the major cause of morbidity and mortality. Most researchs in past time was directional on finding new biomarkers with greater sensitivity and specificity in detection of neonatal sepsis. The aim of our study was to investigate if presepsin obtained from tracheal asprate in intubated newborns, can be a novel biomarker of systemic bacterial infection. Our "case control" study included 60 newborns, 11 with suspected neonatal sepsis. Tracheal aspirate for examination was taken in the usual toilets, in aseptic conditions, by lavage with $2 \mathrm{ml}$ of $0.9 \% \mathrm{NaCl}$ in Mucus suction set. In the same day were mesured presepsin (blood), CRP, PCT, leukocytes and neutrophyls, as well as blood culture. Our research showed higher levels for PCT and presepsin (blood) in septic newborns, as well as in newborns with clinical signs of SIRS. Presepsin obtained from a tracheal aspirate had high score for septic newborns. As the coefficients of simple linear correlation showed, there was quantitative agreement between presepsin (blood) with presepsin (tracheal aspirate)-increase in the value of one leads to an increase in other. In conjunction with an already validated markers of infection, presepsin obtained from tracheal aspirate cam be turned on in diagnostic procedures.
\end{abstract}

Key words: newborn, presepsin, tracheal aspirate,

sepsis.

\section{SAŽETAK}

U odsustvu jasnih kliničkih znakova i definicije, neonatalna sepsa još uvek ostaje jedan od vodećih uzroka neonatalnog morbiditeta $i$ mortaliteta. Većina istraživanja, u poslednje vreme, bila su usmerena na pronalaženje novih biomarkera sa što većom senzitivnošću i specifičnošću u potvrdi neonatalne sepse. Cilj naše studije bio je da ispitamo da li presepsin dobijen iz trahealnog aspirata novorođenčeta može biti novi marker sistemske infekcije novorođene dece. U studiji "slučajkontrola" učestvovalo je 60 novorođenčadi, njih 11 sa suspektnom sepsom. Trahealni aspirat je uziman pri uobičajenoj toaleti tubusa, u sterilnim uslovima, sa $2 \mathrm{ml} 0,9 \% \mathrm{NaCl}$ pomoću Mucus suction seta. U istom danu su merene vrednosti presepsina (iz krvi), CRP, PCT, leukociti, uz bakteriološku obradu (hemokultura). Istraživanje je pokazalo više vrednosti PCT-a $i$ presepsina (iz krvi) kod novorođenčadi sa neonatalnom sepsom i sa znacima SIRSa. Presepsin iz trahealnog aspirata je imao više vrednosti kod pacijenata obolelih od neonatalne sepse. Kako je pokazao koeficijent proste linearne korelacije, postoji kvantitativno slaganje izmedu presepsina (iz krvi) $i$ presepsina (iz trahealnog aspirata)- visoke vrednosti jednog uzrokuju povećanje vrednosti drugog. Udružen sa drugim potvrdenim markerima infekcije, presepsin dobijen iz trahealnog aspirata može biti uključen u dijagnostičke procedure.

Ključne reči: novorođenče,presepsin, trahealni aspirat, sepsa. sciendo

UDK: 616.94-074-053.31
Ser J Exp Clin Res 2020; 21 (3): 225-230

DOI: $10.2478 /$ sjecr-2018-0021
Corresponding author:

Assistant Dragana Savić, Balkanska 9, 34000 Kragujevac, Serbia, Phone: work + 038134370097 ,

Cell Phone + 038134346633 ,

Mobile Phone + 381658487139 , Fax: +38134370213 , 


\section{INTRODUCTION}

Neonatal sepsis is still one of the major causes of morbidity and mortality worldwide in newborns. Clinically, it can show a diverse clinical signs and there is no clear consensus in neonatal sepsis definition (1). The highest frequency of early neonatal sepsis was noticed in infants with maternal perinatal risk factors such as premature rupture of membrane (PROM), mothers fever, positive vaginal culture etc (2).

In response to bacterial infection phagocytosis, most probably, plays a major role in genererating presepsin (36). Monocytes / macrophages are normally present in the circulation and activation of these cells physiologically exist. Early increase in its concentration indicates a bacterial infection and an increase in its intensity depends on the innate immune response $(3,7)$. The sCD14 is significantly elevated in patients with sepsis and septic shock in comparison with healthy people, which is substantially relateed to the severity and prognosis (3-6).

Most researches in recent years were determined to find new biomarkers with greater sensitivity and specificity in detection of early-onset neonatal sepsis. Presepsin, soluble CD14 subtype (sDC14-ST), is well known biomarker of systemic bacterial infections. Isolated from blood, it proved to be more accurate biomarker of earlyonset sepsis compared to procalcitonin (PCT) and C-reactive protein (CRP) $(8,9)$. Obtained from tracheal aspiration presepsin proved to be significant in the diagnosis of early neonatal pneumonia (9). Variables that are affecting C-reactive protein and procalcitonin values do not affect presepsin levels. Accordingly, presepsin independently, can be an effective sepsis marker (10). However, the efficacy of presepsin for the detection of disease severity or prognosis is still being investigated (11).

The aim of our study was to investigate significance of determination and interconnectedness between presepsin (blood) and presepsin (obtained from tracheal aspirate) in intubated newborns in the presence of maternal risk factors associated with clinical signs for early onset neonatal sepsis.

\section{METHODS}

In this study we included 60 newborns hospitalized in Department of neonatology, in Pediatric Clinic, Clinical Center Kragujevac. According to the following criteria, we selected examined group (with 11 newborns):

- Two of the following signs including fiver or deviation of the number of leukocytes determine the systemic inflammatory response (SIRS): fever $\left(>38^{\circ} \mathrm{C}\right)$, hypothermia $\left(<38^{\circ} \mathrm{C}\right)$, tachycardia $(>180 / \mathrm{min})$, bradycardia $(<100 / \mathrm{min})$, tachypnea $(>40 / \mathrm{min})$, systolic TA $(<65 / 8.7$ $\mathrm{mmHg} / \mathrm{kPa})$, leukocytosis $\left(>30 \times 10^{9} / \mathrm{L}\right)$ and leukopenia $\left(<7.5 \times 10^{9} / \mathrm{L}\right)$.
Presence of one or more of the following clinical signs determines possible signs of neonatal sepsis: respiratory distress, apnea, cyanosis, compromised circulation, enteral feeding intolerance, unexplained jaundice, lethargy, hypotonia, seizures and irritability .

Presence of one or more of the following risk factors (PROM $\geq 18$ hours), maternal infections, maternal fever, chorioamnionitis .

In control group we included 49 newborns, without mentioned signs.

All blood analyzes were conducted on the first day of the life. Blood and tracheal samples were collected by standard techniques and used for leukocyte count (NIHON KOHDEN Celltae E), CRP (by immuno- turbidimetric), PCT (by hemi- luminescent immunoassay), presepsin level in blood and plasma (by immunoanalyzer- PATHFAST) and blood culture assessment.

Tracheal aspirate was obtained under sterile conditions by lavage with $2 \mathrm{ml}$ of $0.9 \% \mathrm{NaCl}$ at the time of the usual toilet tube using the "Mucus suction set" (FG 6, or 8 depending on the size of the intratraheal tube) - Protos Company medical.

According to the Declaration of Helsinki, the study protocol and prior to initiation written informed consent was obtained from The regional Ethics Committee of University Clinic Center in Kragujevac,

\section{Statistical analysis}

Using G-power software, we calculated the sample size for our study. Calculated on the basis of the differences in the presepsin level from previous investigations in 41 patients (25male- 16 female) with $294,2 \pm 121,4 / 817,9 \pm$ 572,7 presepsin level ratio (14), with the effect size of 0.849 and with $\alpha$ error probe of 0.05 and study power of 0.9 , we calculated that we needed the minimum of 9 patients with pneumonia in the experimental group and the minimum of 18 patients in the control group.

Information on basic characteristics of the sample were processed and presented by descriptive statistics, with the mean values \pm SD for continuous variables and frequency (percentages) for categorical variables. We used parametric (Student's) $t(t)$ test, nonparametric Mann-Whitney test $(Z)$ test and $X^{2}$-squared test $\left(x^{2}\right)$. The linear correlation coefficient, was used to measure the interactive relationship between variables

\section{RESULTS}

This "cross-sectional" clinical study included 60 newborn children, divided in 2 groups: 11 in the examined group and 49 in the control group. Whole study included 37 male and 23 female newborns. The data stratification according to gender $(p=0,221)$, gestational age $(p=0,335)$, birth body weight $(p=0,275)$ and Apgar score $(p=0,354)$ did 
Table 1. Demographic characteristics of patients

\begin{tabular}{llll}
\hline variable & I & II & $\begin{array}{l}\text { The value and } \\
\text { significance } \\
\text { of the tests }\end{array}$ \\
\hline $\begin{array}{l}\text { gender }(\mathbf{m} / \mathbf{f}){ }^{*} \\
\text { \% }\end{array}$ & $45.5 / 54.5$ & $65.3 / 34.7$ & $\begin{array}{l}\mathrm{X} 2=1.498 \\
\mathrm{p}=0.221\end{array}$ \\
$\begin{array}{l}\text { gestational age } \\
(\bar{X}, \text { weeks })\end{array}$ & $32.91 \pm 4.16$ & $34.31 \pm 4.34$ & $\mathrm{t}=0.972$ \\
$\begin{array}{l}\text { birth body weight } \\
(\bar{X}, \text { grams) }\end{array}$ & $2080 \pm 858.7$ & $2454.69 \pm 1050.57$ & $\mathrm{t}=1.101$ \\
$\begin{array}{l}\text { Apgar score } \\
(\mathbf{1} \text { st min })\end{array}$ & $6.45 \pm 2.58$ & $5.78 \pm 2.76$ & $\mathrm{p}=0.275$ \\
\hline
\end{tabular}

I group- examined; II group- control

* m- male, $f$ - female

Source: own research made in SPSS 20.0

Table 2. Risk factors for infection

\begin{tabular}{|c|c|c|c|}
\hline variable & I & II & $\begin{array}{l}\text { The value and } \\
\text { significance } \\
\text { of the tests }\end{array}$ \\
\hline $\begin{array}{l}\text { delivery way } \\
(\mathrm{SC} / \mathrm{N}) \%{ }^{\circ}\end{array}$ & $45.5 / 54.5$ & $65.3 / 34.7$ & $\begin{array}{l}x^{2}=1.498 \\
p=0.221\end{array}$ \\
\hline $\begin{array}{l}\text { amniotic fluid } \\
(\mathrm{b} / \mathrm{o}) \% \% \%\end{array}$ & $72.7 / 27.3$ & 71.4 / 28.6 & $\begin{array}{l}x^{2}=0.007 \\
p=0.931\end{array}$ \\
\hline $\begin{array}{l}\text { maternal infection } \\
\text { (yes/no) \% }\end{array}$ & $36.4 / 63.6$ & $2 / 98$ & $\begin{array}{l}X^{2}=13.854 \\
\mathbf{p}=\mathbf{0 . 0 0 0}\end{array}$ \\
\hline $\begin{array}{l}\text { maternal fever (yes/ } \\
\text { no) } \%\end{array}$ & $18.2 / 81.8$ & $2 / 98$ & $\begin{array}{l}X^{2}=4.927 \\
\mathbf{p}=\mathbf{0 . 0 2 6}\end{array}$ \\
\hline $\begin{array}{l}\text { positive maternal } \\
\text { culture (yes/no) } \%\end{array}$ & $0 / 100$ & $4.1 / 95.9$ & $\begin{array}{l}x^{2}=0.464 \\
p=0.496\end{array}$ \\
\hline $\begin{array}{l}\text { PROM } \% \text { *\% } \\
>18 \mathrm{~h}(\text { yes } / \text { no })\end{array}$ & 36.4 / 63.6 & $2 / 98$ & $\begin{array}{l}X^{2}=13.854 \\
\mathbf{p}=\mathbf{0 . 0 0 0}\end{array}$ \\
\hline $\begin{array}{l}\text { Transport } \\
\text { (yes/no) }\end{array}$ & $54.5 / 45.5$ & $46.9 / 53.1$ & $\begin{array}{l}x^{2}=0.208 \\
p=0.931\end{array}$ \\
\hline
\end{tabular}

I group- examined; II group- control

"SC-Sectio cesarea; N- natural conception

**b- brighnt; o (other)- milky, cloudy, green or meconial

***:PROM- premature rupture of membranes

Source: own research made in SPSS 20.0 not show significant differences in regard to frequency between examined and control groups (Table 1).

Statistical analyzis showed that maternal infections in the last trimester of pregnancy and premature rupture of membranes were highly significant risk factors for the occurrence of infections in early neonatal period $(\mathrm{p}<0,01)$. Maternal fever has also proved to be a significant factor $(p<0,05)$, while positive maternal swabs to bacterial infections didn't show statistical significance $(\mathrm{p}>0,05)$ (Table 2 ). We investigated if there was a statistically significant difference between factors of inflammation: leukocyte, neutrophils, CRP, PCT, presepsin (blood) and presepsin (tracheal aspirate). None of these factors has proved to be a valuable for the diagnosis of early neonatal infection $\left(\mathrm{p}_{1}\right.$ $=0.354, \mathrm{p}_{2}=0.257, \mathrm{p}_{3}=0.276, \mathrm{p}_{4}=0.256, \mathrm{p}_{5}=0.115$ and $\mathrm{p}_{6}$ $=0.219)$ (Table 3$)$.

Correlation and regression: Coefficients of simple linear correlation showed statistically significant connection between presepsin (plasma) and the type of delivery, sort of amniotic fluide, leucocyte count, CRP, PCT and presepsin (tracheal aspirate).

Extremely low value of the correlation coefficient $r$, $\mathrm{r}_{\text {sepsis }}=0.032 ; \mathrm{r}_{\text {sirs }}=0.0162$ and their statistical significance $\mathrm{p}_{\text {sepsis }}=0.808>\alpha=0.05 ; \mathrm{p}_{\text {sirs }}=0.221>\alpha=0.05$ showed that there wasn't a statistically significant quantitative agreement between: presepsin (blood) and sepsis as well as presepsin (blood) and SIRS (Table 4).

Contrary, low statistical significance $\mathrm{paf}=0.003<\alpha$ $=0.05$ indicated the presence of statistically significant correlation between variables: presepsin (blood)- sort of amniotic fluid. For the CRP, PCT and presepsin (tracheal aspirate), correlation coefficient also showed high statistical significance between those variables and presepsin (blood). Also, it was detected low statistical significance $(p=0.025,<\alpha=0.05)$ for variables type of delivery- presepsin (plasma). Type of delivery was measured for caesarean section, which means that there will be higher values

Table 3. Values of laboratory parameters of inflammation in both groups

\begin{tabular}{|c|c|c|c|}
\hline variable $(\bar{x})$ & I & II & $\begin{array}{l}\text { The value and } \\
\text { significance of the tests }\end{array}$ \\
\hline leukocytes $\times 10^{9}$ & $23.127 \pm 9.673$ & $16.726 \pm 13.887$ & $\begin{array}{l}\mathrm{Z}=-0.926 \\
\mathrm{p}_{1}=0.354\end{array}$ \\
\hline neutrophils \% & $61.527 \pm 9.672$ & $56.535 \pm 13.599$ & $\begin{array}{l}\mathrm{t}=1.145 \\
\mathrm{p}_{2}=0.257\end{array}$ \\
\hline CRP mg/l & $3.45 \pm 1.445$ & $2.90 \pm 1.418$ & $\begin{array}{l}\mathrm{Z}=-1.090 \\
\mathrm{p}_{3}=0.276\end{array}$ \\
\hline PCT ng/l & $25.111 \pm 36.968$ & $9.721 \pm 11.964$ & $\begin{array}{l}\mathrm{Z}=-1.137 \\
\mathrm{p}_{4}=0.256\end{array}$ \\
\hline Presepsin (blood) $\mathrm{pg} / \mathrm{ml}$ & $828.545 \pm 348.618$ & $681.495 \pm 460.612$ & $\begin{array}{l}\mathrm{Z}=-1.576 \\
\mathrm{p}_{5}=0.115\end{array}$ \\
\hline Presepsin (traheal aspirate) $\mathrm{pg} / \mathrm{ml}$ & $695.100 \pm 652.1$ & $429.393 \pm 387.3$ & $\begin{array}{c}\mathrm{t}=1.300 \\
\mathrm{p}_{6}=0.219\end{array}$ \\
\hline
\end{tabular}

I group- examined; II group- control

Source: own research made in SPSS 20.0 
Table 4. Coefficients of simple linear correlation Y-presepsin (blood) in sepsis

\begin{tabular}{|c|c|c|}
\hline variable $(\mathrm{X})$ & $\begin{array}{c}\text { correlation } \\
\text { coefficient }\end{array}$ & significance $\mathrm{p}$ \\
\hline & I & II \\
\hline type of delivery & ,255 & ,025 \\
\hline amniotic fluid (af) & ,347 & ,003 \\
\hline gestational age (ga) &, 067 & ,305 \\
\hline birth body weight (bbw) & 079 & 273 \\
\hline apgar score & 016 & ,450 \\
\hline leukocytes (l) & ,270 & 019 \\
\hline neutrophils (n) &,- 133 & ,156 \\
\hline CRP & ,231 & ,038 \\
\hline PCT & ,329 & ,005 \\
\hline Sepsis & 032 & ,808 \\
\hline SIRS & 0,162 & ,221 \\
\hline presepsin (blood) (ppl) & 1,000 & \\
\hline presepsin (tracheal aspirate) (pta) &, 317 & ,007 \\
\hline mathernal infection (mi) & ,053 & ,342 \\
\hline
\end{tabular}

Source: own research made in SPSS 20.0

for presepsin (blood) in the caesarean section contrary to spontaneous type of delivery. All data are in table 4.

Graphic 1, present neonatal infection distribution.

\section{DISCUSION}

In this "cross-sectional" study we have evaluated the use of presepsin obtained from tracheal aspirate in intubated newborns, hospitalized in neonatal intensive care units (NICU). According to our knowledge, there is no literature data showing the association of presepsin from tracheal aspirate and neonatal sepsis onset. Patients from our examined group weredetected and included in investigation as the patients with high chances of neonatal systemic

\section{Neonatal infections}

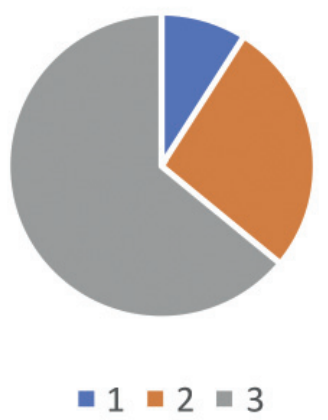

1- Sepsis; 2- SIRS; 3 - other

Graphic 1. Distribution of neonatal infections infections. Beside high perinatal risk factors, they were intubated on the first day of the hospitalization. It was interesting that only $9 \%$ of patients in this group had positive blood culture and $27 \%$ of them had elevated inflammatory parameters associated with signs of SIRS.

The main challenge for our research is that no measurements of presepsin from tracheal aspirate have ever been performed. In the absence of other experiences, we conducted our independent research. Some authors have investigated the use of presepsin obtained from cerebrospinal fluid (CSF) in the case of the meningitis and ventriculitis in children. Measurements of presepsin levels in CSF, showed that it can be added to the diagnostic process in conjunction with biochemical analysis of CSF (12). Only a minor increase of presepsin level in serum was detected in patients with intracerebral infection. In contrast to this knowledge, the same authors stated that dramatically elevated concentrations of presepsin were detected in CSF in experimental murine model study (13). Similar findings were reported in the study of presepsin levels measured in synovial fluid in patients with various stages of Lyme disease (14). Synovial fluid presepsin level was elevated compared to the serum level from healthy individuals, which may play a role in the pathogenesis of arthritis $(13,14)$.

It was sugested that presepsin (blood) is significantly lower in patients without an infection $(294.2 \mathrm{pg} / \mathrm{ml})$ as a complication, versus those with local infection (721 pg/ $\mathrm{ml})$, sepsis $(817.9 \mathrm{pg} / \mathrm{ml})$ and severe sepsis $(1,992.9 \mathrm{pg} / \mathrm{ml})$ (15). Possible role of presepsin in discriminating bacterial and nonbacterial infections (including systemic inflammatory response syndrome) have also been under discussion. In multicenter prospective study, authors compared sCD14-ST with procalcitonin (PCT), interleukin-6 (IL-6) and blood cultures. In comparision to conventional inflammatory blood markers and blood culture, presepsin was superior marker for the diagnosis of sepsis (16).

Our research also showed higher levels for PCT and presepsin (blood) in septic newborns, as well as in newborns with clinical signs of SIRS. Presepsin obtained from a tracheal aspirate was elevated in septic newborns compared to the control, but without significance. It was shown to be more precise in neonatal pneumonia than in neonatal sepsis (9).

Although PCT was higher in septic newborns, there were no statistically significant differences between the groups in our investigation. Results revealed similar finding for CRP level. As described earlier, CRP and PCT can have high blood levels after multiorgan failure in the presence of autoimmune diseases (14). Some studies, reported that serum levels of CRP could also increase in non-infected neonates with perinatal asphyxia, intracranial hemorrhage, pneumothorax, or after resuscitation, and these conditions had negatively affected the specificity of PCT (17). These findings could be an explanation for our findins of higher levels of PCT in both groups without statistical significance, without increased levels CRP increase. 
In general, procalcitonin is more sensitive for earlier detection of sepsis than CRP $(18,19)$. CRP levels rise within 6 to $8 \mathrm{~h}$ of infection, with a peak at $24 \mathrm{~h}$. It has its best predictive value if measured within 24 to $48 \mathrm{~h}$ of onset of infection (18). As we measured CRP levels within first 6 to 10 hours, it was expected that CRP levels were approximately the same in both groups.

It was shown that PCT level is significantly higher in septic and infants with suspected infection in comparison with healthy group (20), which is in alignment with our results.

As the coefficients of simple linear correlation showed, there was quantitative agreement between presepsin (blood) with presepsin (tracheal aspirate). This leads us to the conclusion that presepsin (blood) and presepsin (tracheal aspirate) can be a significant marker of early neonatal infection. As value of presepsin (tracheal aspirate) are in positively correlatoion with presepsin (blood), increase in the value of one leads to an increase in other. Newborns in NICU are mostly hemodynamically unstable and taking blood for analysis additionally compromises them. In intubated newborns in NICU, tracheal aspirate in usual toilet of tube can be simply taken as uninvasive procedure. That makes presepsin from the tracheal aspirate one of the first markers to recognize neonatal sepsis, in conjuction with already used markers.

\section{CONCLUSION}

Presepsin obtained from tracheal aspirate can be used in diagnostic procedures in conjunction with already validated markers of infection. However, we ere aware that the sample size in our study could be interpreted as modest. This limitation discouraged us to make a final conclusions about possibility of the use of presepsin (tracheal aspirate) as an early marker in neonatal sepsis. Considering quantitative agreement with presepsin (blood), it would be justifiable to carry out additional tests on a larger group of patients to confirm our hypothesis.

\section{CONFLICT OF INTEREST}

Authors report no conflict of interest.

This paper has no funding source

\section{REFERENCES}

1. Raymond SL, Stortz JA, Mira JC, Larson SD, Wynn JL, Moldawer LL. Immunological Defects in Neonatal Sepsis and Potential Therapeutic Approaches. Front Pediatr 2017;5(14);DOI:10.3389/fped.2017.00014.

2. Mukhopadhyay S, Puopolo KM. Risk Assessment in Neonatal Early-Onset Sepsis. Seminars in perinatology. 2012;36(6):408-15; DOI:10.1053/j.semperi.2012.06.002
3. Liu B, Chen Y.X., Yin Q, Zhao Y.Z., Li C.S. Diagnostic value and prognostic evaluation of Presepsin for sepsis in an emergency department. Critical Care 2013, 17:R244;DOI:10.1186/cc13070.

4. Ishikura $H$, Nishida T, Murai A, Nakamura Y, Irie Y, Tanaka J et al. New diagnostic strategy for sepsis-induced disseminated intravascular coagulation: a prospective single-center observational study. Critical Care 2014,18:R19;DOI:10.1186/cc13700.

5. Spanuth E, Ebelt H, Ivandic B, Werdan K. Diagnostic and prognostic value of presepsin (soluble CD14 subtype) in emergency patients with early sepsis using the new assay PATHFAST Presepsin. 21st International Congress of Clinical Chemistry and Laboratory Medicine, IFCC-WorldLab - EuroMedLab, Berlin, 15 -19 May 2011. Poster 0333.

6. Wu J, Hu L, Zhang G, Wu F, He T. Accuracy of Presepsin in Sepsis Diagnosis: A Systematic Review and Meta-Analysis. PLoS ONE 10(7):e0133057.DOI: 10.1371/ journal.pone.0133057.

7. Faix JD. Presepsin - The new kid on the sepsis block. Clin Biochem. 2014 May;47(7-8):503-4;DOI:10.1016/j.

8. Montaldo P, Rosso R, Santantonio A, Chello G, Giliberti P. Presepsin for the detection of early-onset sepsis in preterm newborns.. Pediatr Res. 2017 Feb;81(2):32934;DOI:10.1038/pr.2016.217.

9. Savić D, Simović A, Marković S, Kostić G, Vuletić B, Radivojević S, Lišanin M, Igrutinović Z, Pavlović R. The Role of Presepsin Obtained from Tracheal Aspirates in the Diagnosis of Early Onset Pneumonia in Intubated Newborns. Indian J Pediatr. 2018 Apr 14;DOI:10.1007/ s12098-018-2676-2. [Epub ahead of print]

10. Pugni L, Pietrasanta C, Milani S, Vener C, Ronchi A, Falbo $M$ et al. Presepsin (Soluble CD14 Subtype): Reference Ranges of a New Sepsis Marker in Term and Preterm Neonates. PLoS One 2015;10(12):e0146020;D OI:10.1371.

11. Topcuoglu S, Arslanbuga C, Gursoy T, Aktas A, Karatekin $G$, Uluhan $R$, Ovali F. Role of presepsin in the diagnosis of late-onset neonatal sepsis in preterm infants. J Matern Fetal Neonatal Med. 2016;29(11):18349;DOI:10.3109/14767058

12. Stubljar D, Kopitar AN, Groselj-Grenc M, Suhadolc K, Fabjan T, Skvarc M. Diagnostic Accuracy of Presepsin (sCD14-ST) for Prediction of Bacterial Infection in Cerebrospinal Fluid Samples from Children with Suspected Bacterial Meningitis or Ventriculitis. J Clin Microbiol 2015;53(4):1239-44;DOI: 10.1128/JCM.03052-14.

13. Sansano S, Fearns C, Ulevitch R, Zimmerli W, Landmann $\mathrm{R}$. The origin and function of soluble CD14 in experimental bacterial meningitis. J Immunol 1999;162:4762-72.

14. Lin B, Noring R, Steere AC, Klempner MS, Hu LT. Soluble CD14 levels in the serum, synovial fluid, and cerebrospinal fluid of patients with various stages of Lyme disease. J Infect Dis 2000;181(3):11858;DOI:10.1086/315357. 
15. Shozushima T, Takahashi G, Matsumoto N, Kojika M, Okamura Y, Endo S. Usefulness of presepsin (sCD14-ST) measurements as a marker for the diagnosis and severity of sepsis that satisfied diagnostic criteria of systemic inflammatory response syndrome. J Infect Chemother 2011;17(6):764-9;DOI:10.1007/ s10156-011-0254-x.

16. Endo S, Suzuki Y, Takahashi G, Shozushima T, Ishikura $\mathrm{H}$, Murai A et al. Usefulness of presepsin in the diagnosis of sepsis in a multicenter prospective study. J Infect Chemother 2012;18(6):891-7;DOI:10.1007/s10156012-0435-2.

17. Janota J, StranákZ, BĕlohlávkováS, Mudra K, SimákJ.Postnatal increase of procalcitonin in premature newborns is enhanced by chorioamnionitis and neonatal sepsis. Eur J
Clin Invest. 2001 Nov; 31(11):978-83;DOI:org/10.1046/ j.1365-2362.2001.00912.x

18. Simonsen KA, Anderson-Berry AL, Delair SF, Davies HD. Early-Onset Neonatal Sepsis. Clinical Microbiology Reviews 2014;27(1):21-47; DOI:10.1128/CMR.00031-13.

19. Wellinghausen N, Kochem AJ, Disqué C, Mühl H, Gebert $\mathrm{S}$, Winter $\mathrm{J}$ et al. Diagnosis of bacteremia in whole-blood samples by use of a commercial universal 16S rRNA gene-based PCR and sequence analysis. J Clin Microbiol 2009;47(9):2759-65.;DOI: 10.1128/ JCM.00567-09.

20. Adib M, Bakhshiani Z, Navaei F, Saheb Fosoul F, Fouladi S, Kazemzadeh H. Procalcitonin: A Reliable Marker for the Diagnosis of Neonatal Sepsis. Iranian Journal of Basic Medical Sciences. 2012;15(2):777-782. 